\title{
Hostess brands inc.: A case study
}

Kimberly J. Flanders

Indiana University of Pennsylvania, United States

\section{Keywords}

Case study, human performance technology, instructional design, business process improvement

\begin{abstract}
Hostess Brands, Inc. served as the largest manufacturer and distributor of baked goods products in the United States for decades. Throughout numerous mergers and acquisitions, the company's growth resulted in a series of problems leading to bankruptcy. The three key problems included high legacy costs, shrinking profits, and significant, long-term debt. This research is a case study utilizing Gilbert's Behavioral Engineering Model to evaluate the issues that led to the bankruptcy of Hostess Brands, Inc.
\end{abstract}

Corresponding author: Kimberly J. Flanders

Email address for corresponding author: tswjvab@iup.edu

First submission received: 8th March 2017

Revised submission received: 1st May 2017

Accepted: 10th June 2017

\section{Introduction}

The largest producer and distributor of baked goods products in the United States, Hostess Brands, Inc. filed for bankruptcy on November 16, 2012. Several problems existed within the organization that made solvency and profitability nearly impossible. Three key problems uncovered within the organization included exorbitant legacy costs due to multiple unions, shrinking profit margins because of increased production costs, and large, long-term debt. This study will evaluate human performance technology, specifically analyzing the main problems within Hostess Brands, Inc., and will also argue for Gilbert's Behavioral Engineering Model, discussing how it could have been utilized to improve Hostess organizational efficiency.

\section{Hostess Brands, Inc.}

Hostess Brands, Inc. baked and distributed breads and baked goods throughout the United States from 2009 to 2013. This corporation emerged from bankruptcy in 2009, then owned by Ripplewood Holdings LLC, a private equity firm, and retained financing through hedge Silver Point Capital LP and Monarch Alternative Capital LP (Feintzeig, 2012). Some of the most common product lines included Wonder Bread, Hostess, and Dolly Madison, along with several other popular brands. Once the company was fresh out of bankruptcy under Interstate Baking Company (IBC), it began to operate again under the Hostess Brands, Inc. name, aspiring to succeed as a profitable venture by providing bakery items throughout the country.

Headquartered in Irving, TX, Hostess Brands, Inc. owned and operated 36 bakeries that manufactured products which were delivered to approximately 600 distribution centres, where nearly 6000 delivery drivers distributed product to stores (sbwire.com, 2012). In total, the company employed over 18,500 employees (cnn.com, 2012). The Hostess timeline goes back nearly a century. In 1919, the first product was introduced, known then as the Hostess Cupcake (hostesscakes.com, 2016). Continental Baking Company purchased Taggart Bakery in 1925, which made Continental Baking Company the largest bakery in the United States (cnn.com, 2012). Interstate Baking Company (IBC) was formed in Kansas City, Missouri in 1930, the same year that James Dewar of Continental Bakery invented the Twinkie. Throughout the 1920s, and through the late 1990s, Interstate Baking Company purchased and acquired numerous smaller wholesale bakeries; and, in 1995 they acquired 
the Continental Baking Company for $\$ 330$ million, plus stock (cnn.com, 2012). This acquisition made IBC the largest wholesale bakery in the United States.

In October 1998, Interstate Baking Company's stock fell nearly $25 \%$ in a mere two hours, following the announcement that earnings were indeed less than expected (fundinguniverse.com, 2016). Plunging from a high of $\$ 34.375$ per share down to $\$ 22.75$ per share in only a year, the company created a shareholder rights plan to prevent any possible takeovers. Further financial struggles plagued the company in 2000, when net earnings were \$37 million less than in 1999, finishing the year with earnings of $\$ 89$ million.

In the late 1990s and early 2000s, cost of production increased significantly due to increased prices for main ingredients such as flour and sugar. Gasoline prices also continued to climb during that time. Since IBC products generally carried a high price tag, the market could not support higher sales prices, so profit margins were squeezed, causing further financial burdens for the already overleveraged company. In 2004, IBC filed for Chapter 11 bankruptcy.

\section{Hostess Brands, Inc. Financial Struggles}

Restructuring after the previous bankruptcy, Hostess Brands, Inc. was then required to carry an exorbitant amount of legacy costs. With the acquisition of numerous other wholesale bakeries, Hostess Brands, Inc. also acquired numerous labor unions, which made-up the largest employee population within the organization. The system was quite complex, as it then held 372 separate bargaining contracts for employees (Feintzeig, 2012). Additionally, the numerous mergers included pension and health care plans, along with other specific benefit packages. These contracts carried excessive financial burdens due to the administrative fees that were associated with each individual plan; and, these plans varied in accordance with the bargaining unit of the original contract.

Further, the company struggled with a vast production system and over 5,500 truck delivery routes. These delivery routes created significant inefficiencies and additional expenses to the company as they often-times crossed over one another. Regardless, union contracts prohibited any streamlining of the process.

Known for selling products high in sugar and carbohydrates, Hostess Brands, Inc. did not adequately market products sought by fitness-oriented consumers. They struggled to attract new customers due to lack of product variety and ingredients, which could have included the use of healthier grain breads over the traditional white breads (wsj.com, 2012). Therefore, product sales remained flat, including the sales of Twinkies, which declined by $2 \%$ (Isidore, 2012). Profit margins continued to shrink, due to Hostess' inability to increase consumer pricing. Production and delivery costs continued to increase, partially due to already high initial pricing (wsj.com, 2012). This, combined with the initial debt acquired by Hostess Brands, Inc. of approximately $\$ 860$ million, made the company's financial goals nearly unreachable.

\section{Theoretical Perspectives}

When evaluating the performance of the Hostess Brands, Inc. as an organization, behaviorism theory may be utilized to examine the external environment of the labor unions, which had represented and advised the employees. Due to the differences in opinions and concessions made among the leaders of the various bargaining units, a comprehensive understanding of the initiatives made by all parties involved did not exist. Therefore, no sensible efforts were ever made, which may have potentially saved the organization from financial disaster.

Arguably, by enacting a human performance technology model such as Gilbert's Engineering Behaviors Model (1978), Hostess Brand, Inc. could have created more favorable discussions and better understanding between all interested parties. Further understanding of the inefficiencies and redundancies in Hostess delivery routes can be made through an assessment process, where sound recommendations can be arrived at, applicable to business operations in financially troubled organizations such as Hostess. 


\section{Data}

To effectively analyze the details behind the bankruptcy of Hostess Brands, Inc., it was necessary to review both the Disclosure Statement as well as the First Day Declaration made by Hostess Brands, Inc. during their bankruptcy proceedings. These two documents contain valuable details that can be used to better examine of challenges the company faced that fostered insolvency and ultimate bankruptcy in 2012. In addition to these two extensive documents, a prior case study conducted by Ganier, Conrad, and Patrick (2013) can be utilized to make sound recommendations for improvements in organizational performance.

After reviewing these documents, it is sensible to further explore the roles that the numerous unions had played in company performance. According to the neoclassical economic model, competitive markets drive companies to operate as efficiently as possible, thus prohibiting unions from improving the performance of these companies (Belman, 1992). By prioritizing the needs of its members, unions can cause wages to be higher than they typically would be for similar non-union jobs, sometimes utilizing the threat of a labor strike (Sherk, 2009). The primary functions of labor unions are to ensure pay equality as well as to maintain favorable working conditions for employees. However, unions continue to face a decline in popularity due to their ineffectiveness in accomplishing their labor goals (Malik, 2011).

Previous research indicates that union labor organizations may provide valuable improvement in human performance. Belman compared research results from numerous scholars, finding that unions actually improved efficiency in some organizations (1992). Further research indicates that organizations that utilize union employees have a larger number of highly effective, high-performance work practices (Gittell, 2004).

During the Hostess Brands, Inc. financial crisis, the company had asked employees to concede and also to not strike. Although some of the unions agreed to continue to work, the decision was not mutual among all union leaders, so many of the unions began to strike. On the fourth day of the strike, Hostess Brands, Inc. announced that it was indeed filing for bankruptcy.

In a press release dated November 16, 2012, AFL-CIO President Richard Trumka states:

“What's happening with Hostess Brands is a microcosm of what's wrong with America, as

Bain-style Wall Street vultures make themselves rich by making America poor. Crony capitalism and consistently poor management drove Hostess into the ground, but its workers are paying the price. These workers, who consistently make great products Americans love and have offered multiple concessions, want their company to succeed. They have bravely taken a stand against the corporate race-to-the-bottom. And now they and their communities are suffering the tragedy of a needless layoff. This is wrong. It has to stop. It's wrecking America" (aflcio.org, 2012).

In an interview with CNN, Frank Hurt, President of the baker's union remarks:

"Our members decided they were not going to take any more abuse from a company they have given so much to for so many years. They decided that they were not going to agree to another round of outrageous wage and benefit cuts and give up their pension only to see yet another management team fail and Wall Street vulture capitalists and 'restructuring specialists' walk away with untold millions of dollars."(cnn.com, 2012).

The inability for all union leadership to agree on concessions sealed the fate of Hostess Brands, Inc. on November 16, 2012, resulting in the loss of over 18,500 jobs (Brown, 2014).

\section{Possible Solutions}

Three potential business solutions emerge through evaluation of Hostess Brands, Inc. and application of Gilbert's Behavioral Engineering Model to the former organization. These three solutions include streamlining driver delivery routes, outsourcing product delivery, and the elimination of in-house product delivery. Improved communications between the labor unions and clearly agreed-upon company goals would also have greatly benefitted Hostess. 
By working with the employees and the union representatives, specifically addressing the redundancies in driver routes, the company could have offered incentives to drivers to alter their usual delivery routes. Indeed, this would have fostered greater efficiencies by reducing employee labor costs, lowering fuel expense, reducing wear and tear on the delivery fleet, as well as lessening vehicle insurance premiums. Additionally, by calculating an incentive delivery rate and rewarding drivers for performance, standards could also have been set to address other gaps in operational efficiency.

A second recommendation for performance improvement in Hostess Brands, Inc. would have been to eliminate the company delivery fleet. Hostess then could have hired an external delivery source to manage and deliver the entire product line to the distributors. By eliminating the delivery drivers, several labor unions would have no longer been necessary, along with legacy costs associated with these unions.

Finally, the third possible solution to the organizational problems, which argues for the construct of behaviorism and Gilbert's Behavioral Engineering Model, is to improve communications between all of the labor union representatives and the corporate executives and decision makers in Hostess Brands, Inc. In short, by improving these communications and implementing incentives for agreement among all interested parties, a win/win situation could have been fostered between the organization and all of the employees. Hostess workers needed accurate information, communicated clearly by management. Further, employees could not perform optimally without proper resources and incentives.

It is most important to state that employee motivation and incentives would have encouraged positive behavior, which would have been to the benefit of the corporation and ultimately, all employees. Negative behavior, such as employees taking longer delivery routes and wasting company time and resources, would only have been to the detriment of the company, as well as increasing delivery and product frustrations for clients and customers. By creating this mutual benefit, employee engagement and morale would have improved, and the company could have gained in profitability and operational efficiency. Gilbert's model argues for the need for worker incentives, proper resources, and positive motivation. Indeed, employee mindfulness must be fostered by organizational leaders, in the first place. Unfortunately, complex business circumstances, poor communication, fuzzy organizational goals, and unneeded layers of labor unions, employees, and supervisors did little to lessen Hostess' operational costs, much less give employees incentives for mindfulness, efficiency, and the ultimate good of the company.

\section{Recommended Solution}

Due to the extreme complexity of the organization, along with the extent of labor unions, pension plans, administrative costs, while attempting to keep pace with numerous contractual obligations, the recommended solution is the outsourcing of product delivery to a third party. By eliminating the route redundancies, along with the costs associated with retaining double the delivery routes as well as delivery drivers, the company would have had to eliminate nearly 600 employees. This would have reduced immediate payroll expense, health care costs, and the administrative expenses that will be associated with a large workforce. Additionally, this would have decreased the number of various labor unions and their leaders, simplifying bargaining and contract negotiations. This would have made agreement on the company's future clearer, and any union problems that might have cropped up could have been dealt with in far less complicated ways. In short, union engagement with upper management would have been more sensible and efficient, benefitting a financially troubled company that was in dire need of better communication at all organizational levels. 


\section{Summary}

Hostess Brands, Inc. served as the largest manufacturer and distributor of baked goods in the United States from 2009-2012. Unfortunately, due to several factors, including high production costs, lack of health-conscious products, multiple labor unions, extensive pension plans, and significant debt, Hostess Brands, Inc. had to file for bankruptcy in 2012. By being more proactive and taking a deeper dive into human performance technology, Hostess Brands, Inc. could have implemented significant changes to foster a more engaging employee environment, thus improving employee productivity, manufacturing efficiency as well as overall corporate profitability. Specifically, by outsourcing delivery, the company could have experienced substantial financial relief. Indeed, human performance technology and Gilbert's Behavioral Engineering Model was not utilized in order to save Hostess Brands, Inc. from insolvency, but much can be learned from the mistakes, hopefully preventing other businesses from ultimately succumbing to the same fate.

\section{References}

Appelbaum, E. (2015). High-performance work practices and sustainable economic growth. EPRN.

Bamber, G. J., Gittell, J. H., Kochan, T. A., \& Von Nordenflycht, A. (2013). Up in the air: How airlines can improve performance by engaging their employees. Cornell University Press.

Belman, D. (1992). Unions, the quality of labor relations, and firm performance. Unions and economic competitiveness, 41-107.

Brown, A. T. (2014). Points of contention: Oddities, delicacies, \& monstrosities.

Berger, C. J., Olson, C. A., \& Boudreau, J. W. (1983). Effects of unions on job satisfaction: The role of work-related values and perceived rewards. Organizational Behavior and Human Performance, 32(3), 289-324.

Reese, R. (2012, November 21). Retrieved April 27, 2016, from https://www.forbes.com/sites/quora/2012/11/21/did-hostess-go-bankrupt-in-2012because-people-no-longer-find-twinkies-appealing/\#483d2131675d

Feintzeig, R., Spector, M., \& Jargon, J. (2012, November 16). Twinkie maker Hostess to close. Retrieved April 28, 2016, from

http:/ / www.wsj.com/articles/SB10001424127887324556304578122632560842670

Ganier, K. K., Conrad III, F. L., \& Patrick, W. G. (2013). Hostess Brands, Inc. Bankruptcy.

Gilbert, T. F. (1978). Human competence-engineering worthy performance. NSPI journal, 17(9), 19 27.

Gittell, J. H., Von Nordenflycht, A., \& Kochan, T. A. (2004). Mutual gains or zero sums? Labor relations and firm performance in the airline industry. Industrial $\mathcal{E}$ Labor Relations Review, 57(2), 163-180.

Herndon, H. K. Hostess Brands, Inc. and labor relations missteps.

Hostess Brands Company Profile \& SWOT Report. (2012, June 8). Retrieved April 27, 2016, from http:/ / www.sbwire.com/ press-releases/hostess-brands-company-profile-swot-report-147487.htm Hostess Disclosure Statement. (n.d.). Retrieved April 27, 2016, from https://www.scribd.com/doc/113318975/Hostess-Disclosure-Statement

Hostess First Day Declaration. (n.d.). Retrieved April 27, 2016, from https://www.scribd.com/doc/113314243/Hostess-First-Day-Declaration

Hostess Snack Cakes. (n.d.). Retrieved April 27, 2016, from http://hostesscakes.com/about/

Huselid, M. A. (1995). The impact of human resource management practices on turnover, productivity, and corporate financial performance. Academy of management journal, 38(3), 635-672.

Interstate Bakeries Corporation History. (n.d.). Retrieved April 28, 2016, from http:/ / www.fundinguniverse.com/company-histories/interstate-bakeries-corporation-history Isidore, C., \& O'Toole, J. (2012, November 16). Hostess Brands closing for good due to 
bakers strike. Retrieved April 27, 2016, from

http:// money.cnn.com/2012/11/16/news/companies/hostess-closing/index.html

Kaplan, D. A. (2012). Hostess is bankrupt... again. Fortune, July 26.

Malik, M. S., Basit, A. B., \& Qazi, A. K. (2011). Unions and management: A case study of Pakistan Telecommunication Corporation. Pakistan Journal of Social Sciences (PJSS), 31(1), 185-199.

Sherk, J. (2009). What unions do: How labor unions affect jobs and the economy. The Heritage Foundation.

Skinner, B. F. (1974). About behaviorism. New York, Knopf: [distributed by Random House].

Spector, M. \& Jargon, J. (2012, January 10). Twinkies maker preparing for chapter 11 filing. Retrieved April 27, 2016, from

http://www.wsj.com/articles/SB10001424052970204124204577151211961572458

Statement by AFL-CIO President Richard Trumka on Hostess Brands Inc. (2012,

November 16). Retrieved April 27, 2016, from http://www.aflcio.org/Press-Room/PressReleases/Statement-by-AFL-CIO-President-Richard-Trumka-on-Hostess-Brands-Inc

Timeline: The history of Hostess Brands. (2012, January 11). Retrieved April 27, 2016,

fromhttp://old.seattletimes.com/html/businesstechnology/2017210885_apushostessbrandsbankrup tcyfilingtimeline.html 